\title{
PRIMARY MENTAL HEALTH CARE: INDICATIONS AND OBSTACLES
}

\author{
Y.G. Pillay and H. Subedar
}

\section{INTRODUCTION}

This essay critically examines literature that has suggested the need for primary mental health care. In exploring this literature the issue of context as a crucial variable is stressed. Context refers to both the geographic area (South Africa, urban/rural) and the particular type of health service in use. The basic point is that the designation of the primary practitioner is context dependent, be he/her the general practitioner in the United States, the psychiatric nurse in rural South Africa or the public health nurse in an urban context which stresses primary prevention.

In articulating a response to the topic it is useful to ask the following questions:-

(a) what is primary mental health care?

b) who should practice it and where?

c) what types of patients would benefit from it?

(d) what constraints exist which make the practice of mental health care difficult?

\section{A BRIEF REVIEW OF TIIE IISTORICAL DEVELOPMENT OF TIIE CONCEP'T 'PRIMARY IIEALTII CARE'}

Given that there is a thrust to re-incorporate mental health care into primary care, it is pertinent to trace briefly the historical development of primary health care within which primary mental health should be situated. We argue that the attempt is a re-incorporation because the use of psychotherapeutic techniques in the armamentarium of indigenous healers has been well documented (Buhrmann, 1983).

Walt and Vaughan (1982) suggest that there were five basic issues which provided the thrust for the development of primary health care culminating in the Declaration of Alma Ala in 1978. The first was the realization in the 1960's that economic growth was not being equitably distributed and that with growing polarization of the social classes in society, the rich were getting richer and the poor poorer. The number of people with wealth was diminishing, the number of poor was increasing and there was concomitant realization that the poor had very limited or no access to health care despite increasing technological sophistication in the provision of such care.

The second issue was concern about the rapid growth of the world's population associated

\section{Abstract}

This paper considers indications and obstacles for the development of primary mental health care practice in both developed and under-developed countries. Both are considered as this represents the South African reality. While a significant body of literature has documented the need for primary mental health care, the obstacles (especially in terms of the coinmodification of health) to its fruition are seldom addressed.

\section{Uittreksel}

Hierdie referaat beskou indikatore en struikelblokke vir die ontwikkeling van primêre geestesgesondheidsorg in ontwikkelde-sowel as onder ontwikkelde lande. Beide hicrdie word verteenwoordig binne die Suid-Afrikaanse realiteit. Alhoewel 'n aanduidende hoeveelheid literatuur die bchoefte aan primêre geestesgesondheidsorg dokumenteer, word die struikelblokke (spesifiek i.t.v. die gebruikswaarde van gesondheid) selde tot die volle verwerkliking aangespreek.

with concern about competition for a finite amount of natural resources. While this is a real concern, it can also be demonstrated that, at least to some extent, the problem is compounded by the distribution of resources. For instance, in some countries the real issue is land distribution and not a population explosion (Navarro, 1974). This distinction is crucial as it has obvious implications for interventions such as the decision to invest finance and health labour-power in family planning (use of the term 'population control' illustrates the point well) as opposed to advocating land reform.

The third issue was general disill usionment with mechanistic solutions to health problems and the rcalization that, despite icchnoligical advances in health care, the health of the populace was not significantly better. Although it can be argued that the tide has turned since the early 1980s, technical solutions especially in the 1960 s and 1970 s were viewed as being limited and the need for a holistic approach to health including social, economic, educational and political domains was advocated. The need for community based heal th which incorporated all the above dimensions was advanced by workers such as King (Watt \& Vaughan, 1982).

The well-publicised Chinese experiment with community participation and the 'barefoot doctor' and its success in delivering health care to the people was the fourth impetus to the development of the notion of primary health care. It is necessary, however, to contextualise this experiment in terms of the political economy that gave rise to it and not to view it as yet another technical innovation. The Cuban experience and the massive reduction in infant monality rates in a relatively short period of time also added to the appeal of primary health care.

International adoption of the concept came with the World Health Organization's decision in 1975 to strive for provision of basic health services for all by year 2000 and the subsequent adoption by the international community of the Declaration of Alma Ala in 1978 outlining the need for primary health care as the important mcthodology for reaching the goal Health for All by year 2000 .

\section{PRIMARY MENTAL IIEALTII CARE}

(a) The Need for Primary Mental llealth Care : Theoretical Consideration

In defining health the Declaration of A Ima Ata stated that it was the state of complete physical, mental and social well-being of a person. Also documented was the fact that health was influenced by factors beyond the control of the health sector, such as social and economic considerations. Given the contention that at least in some countries one important issue is the need for land reform, it appears necessary to add the political sector to this list. The Declaration includes the spirit of this suggestion in its assertion that people have the right to participate, both individually and collectively, in planning and implementation of health care (and, it may be argued, by extension, to all other facets of civic life).

The Declaration, by including mental health as an essential component of health, provides rationale for the existence of 'primary mental 
health care' as a legitimate concern and area of study. Goldman (1982) suggests other factors that provided the impetus for primary mental health care which are to some extent, parochial to the U.S.A. He argues that with the creation of public assistance by means of Medicare and Medicaid, more money was available for mental health care in general health settings. Secondly, the psychopharmacological revolution made it possible for large numbers of mentally ill people to be treated whilst in the community with maintenance therapy provided by primary mental health practitioners. Thirdly, the rise of the community mental health movement helped to partly de-medicalize and de-stigmatize, mental disorders and probably more importantly "...succeeded in moving mental health concerns into public consciousness" (Goldman, 1982, 619).

The need to prioritize mental health in the provision of primary heal th also is suggested by Sartorius (1988) who argued that mental illness is important because it causes suffering to the individual, the family and the community; it has social/economic consequences such as decreased productivity; increasing life expectancy gives rise to increases in the rates of mental disorders (eg. depression and dementia in the elderly); increases in the level of stress and the fragmentation of the family and other traditional support systems imply the need for alternative support mechanisms and that mental health expertise can help to humanize the delivery of health care.

The nature of primary mental health may be derived from the need for mental health services that are accessible primary care level. This need has been demonstrated by numerous studies of patients presenting to primary health care practitioners, in both post-industrialized and partially industrialized countries, with overt manifestations of mental disorders as well as important covert or masked manifestations such as somatization.

\section{(b)The Need for Primary Mental Health Care: Empirical Evidence}

In developed countries, for example the U.S.A. and Britain and certain sectors of the South African population the regular primary health practitioner is the general practitioner, family practitioner or internist (Lachman and Zwarenstein, 1990). Kramer et al. (in press) found that for the two year period January 1980 to December $1981,45.3 \%$ of all physician office visits were to either the general practitioner or the internist, increasing to $56.4 \%$ when one includes pediatricians. This figure becomes even more relevant when it is realized that general practitioners in Britain are the main providers for $95 \%$ of the population with psychiatric morbidity (Gask and McGrath, 1989).

The picture is further complicated by the finding that treatment rates for mental disorders were very low. Kramer et al. (in press) found treatment rates of $7 \%$ while Beigel (1983) suggested a figure of $15 \%$ which while significantly greater than that found by Kramer et al., is still unacceptably low. This suggests that a very small minority of those who needed treatment were receiving it. Reasons for this are complex but limited access to care, estimated by Kramer et al. to be over 37 million or $16 \%$ of the U.S. population, must be contributory, especially if the assertion that this group represents those most vulnerable to mental illness is valid.

Prevalence rates for mental disorders appear to depend in part on the sensitivity of the screening instrument used. Ormel et al (1990) found that prevalence rates of psychological disorders in patients presenting in general practice in the Netherlands, varied from $46 \%$ when the General Health Questionnaire (GHQ) was used to $15 \%$ when the Present State Examination (PSE) was used. General practitioners seemed able to identify about $56 \%$ of the cases positively identified by the GHQ. Various studies of patients presenting to primary care providers in post-industrialized countries found that "...over a third of consecutive general practitionner attenders show substantial levels of mental distress and that approximately $15-25 \%$ can be assigned a specific diagnosis in the depression and anxiety spectra..." (Ormel et al., 1990, 909).

The World Health Organization (WHO) in their seven country sludy, tried to study the issue in partially developed and under-developed countries. Harding et al (1980) reported that the WHO Collaborative Study on Strategies for Extending Mental Health Care (of four of the countries studied ie. Colombia, India, Philippines and Sudan) found that prevalence rates for consecutively presenting adults ranged from $10.6 \%$ in the Sudanese sample to $17.7 \%$ in the Indian sample. They also found, contrary to expectation as well as priority set by the World Health Organization ie. to target the anticipated large number of psychotics, that of all the patients found to have some form of psychological disturbance, approximately $86 \%$ of them were diagnosed as having some form of neurosis. An equally important finding was the percentage of mentally ill patients who presented with somatic complaints which were missed consistently as indicators of mental illness by the primary health care worker.

The empirical evidence presented above covers developed, partially developed and under-developed countries. This begs the issue as far as South Africa is concerned, given that it includes both a developed society and one that can be described as under-developed. Data that would assist the description of the problem and planning responses are largely unavailable. We have to rely on estimates that are based on some of the research conducted by the World Health Organization. Freeman (1989) suggests that, based on a $15 \%$ prevalence of mental disorders, approximately 5 million people in South Africa have some form of mental disorder with 330,000 being severely incapacitated. He also suggests that mental health resources are inadequate to cope with the numbers of people requiring help. This supports the need for primary mental health services to be provided by a broad range of health care practitioners including general practitioners, nurses, paraprofessionals and indigenous healers who are integrated into the health care system.

\section{(c) Form of Primary Mental Health Care}

While there is considerable agreement about the need for primary mental health care there is less agreement about the form that it should take, suggesting that there is some disagreement about the nature of primary mental health skills necessary. This issue is summarized adequately by Gask and MoGrath (1989). The controversy largely centres around the issue of theoretical orientation (eg. the applicability of psychodynamic theory as opposed to a problem-focused approach) and the related issue of who should practice primary mental health care.

The first issue focuses on the type of intervention primary health care practitioners should be expected to provide. It is the contention of this paper, supported in part by Schurman et al (1985), that primary care practitioners, be they village workers, nurses or general practitioners should not be expected to provide the type of diagnostic or therapeutic intervention which specialist mental health practitioners provide. Nevertheless, primary care practitioners should be trained to make adequate first level diagnoses of mental disorders, make appropriete referrals where possible and possess a therapeutic attitude that permeates their practice and helps humanize the practice of health care.

Despite controversy about theoretical orientation, there is some agreement about a few issues. The importance of a therapeutic attitude has been articulated (Schurman et al., 1985; Gask and McGrath, 1989). This can be a fairly nebulous concept but is seen as consisting of at least the following components:- adequate listening skills, attention to both verbal and non-verbal cues and an empathetic attitude.

In terms of improving the diagnostic ability of primary health care workers, the use of such standardized scales as the GHQ, PSE and the Short Reporting Questionnaire (SRQ) can increase the percenlage of patients with psychological problems identified by the primary care practitioner. Many of these instruments such as the PSE,GHQ and SRQ have been standardized for use in developing countries.

What is more difficult to achieve is the change in altitude of primary health care practitioners to mental disorders. The historical relationship between medicine and psychiatry has been documented by, amongst others, Goldman (1982). Ile suggests that these two branches of health care only recently have begun to talk the same language, with the medicalization of mental disorders facilitated by advances in biological psychiatry. The view of these reviewers is at odds with Goldman who appears to consider this necessarily advantageous. It is possible that as psychiatry becomes subsumed by technology, psychiairy may become as mechanistic as the rest of medicine rather than becoming humanised. 
(d) Some obstacles to the development of Primary Mental Health Care

These authors are not optimistic about the possibility of making health care less mechanistic and more humanistic.

This pessimism rests on the nature of the health care delivery system in most countries, including South Africa. The treatment of health as a commodity on which an exchange value is placed and the degree of professionalization of the health care providers, two related issues, are advanced as reasons for such pessimism.

In terms of the commodification of health and ill-health, the form of the output of services rendered by health practitioners is expected 10 be some physical entity such as drugs or surgery. This parallels all other commodities on which an exchange value has been placed, resulting in what Marx called a materialist economic system (Karasek, 1991). This type of economic system, where the commodity being sold or bought must be physically packaged and transferred from the producer to the consumer, creates obvious difficulty for the sale and purchase of mental health, with its nebulous and intangible quality. The possible exception is the sale of drugs but not even this is entirely true given the nature of mental disorders - unlike physically-damaged tissue, mental illness cannot be demonstrated in a form consistent with the expectations of a materialistic society.

If the provision of mental health services (and ealth generally) is to be widely available and used, the need arises for an alternate form of economy within which the provision of health services may be more adequately provided and used. Karasek has suggested the need for a new form of output value which is related to the use of skill: "In the New Value production ...the producer provides the kind of output that can facilitate the development of new skills or capabilities in the user" (Karasek 1991, 170). Such suggestion postulates the replacement of exchange value with a form of output transfer that does not alienate the producer (in terms of loss of control over his skills) and involves the creation of new skills in the user. De-mystification of knowledge and skills is implied as one cannot help create new skills without sharing the essence of that which is being transferred. It is this that provides the link between the issues of forms of output value and professionalization.

The nature of professionalism is alluded to by Louw (1988) who argues that professionals are largely self-directing in that they have significant autonomy over the content and practice of their area of expertise. Goulder (1979) supports and extends this thesis by proposing that the elitism inherent in professionalism undermines public decision-making as it becomes the only legitimate authority. The 'legitimate' authority which Gouldner discusses is in part beslowed by such activities as accreditation and membership of professional organizations. These activities serve to regulate and 'privatize' knowledge in the hands of a few who thereby acquire enormous power in terms of the use value and exchange value which they are able to generate from the commodity over which they have developed hegemonic control. These professional bodies therefore play a gate-keeping role, making it difficult for true skill-sharing to occcur. It may be argued too, that the narrowly based professional health field makes real collaboration benween the various members of the health team difficult.

There is yet another aspect to the delivery of health care that requires consideration and which is related to the former two and this is the effect of what Salmon (1985) calls the industrialization of health. Hereby reference is made to the wholesale take-over of hospitals by multinational and transnational corporations whose primary interest is to extract the largest possible profit margins. Such strategy is exemplified by the privatization of health services in South Africa by the current government. This would mean that only the barest minimum, in terms of short-term costs, of health care will be provided and then only to those who can afford to pay. The role of health care workers in this situation will be limited as decision making will be made by administrators on the basis of profit margins. Additionally, the use of cost/benefit ratios, which cannot take into consideration intangibles such as 'the therapeutic allitude', could rule out any incentives for healih care systems to provide a labour force sensitive to the mental health care needs of their patients.

\section{CONCLUSION}

This paper has attempted to review the literature on the need for primary health care. It has tried to outline some of the issues related to the development of primary mental health in both developed and developing countries as both areas are represented within South Africa.

It is the contention of these reviewers that while the value of primary mental health care is undeniable, it will not be achieved unless there are accompanying structural changes making possible the internalization of different forms of output values such as those suggested by Karasek (1991).

\section{REFERENCES}

BEIGEL, A. (1983). Community Mental Health Care in Developing Countries. American Journal of Psychiatry 140: 1491-1492.

BUHRMANN, M.V. (1983). Community Health and traditional healers. Psychotherapedia, 30:15-18.

FREEMAN, M. (1989). Mental Health Care in Crisis in South Africa. Paper No. 16. Johannesburg: Center for the Study of Health Policy.

GASK, L., McGRATH, G. (1989). Psychotherapy and General Practice. British Journal of Psychiatry 154:445-453.

GOLDMAN, H.H. (1982). Integrating health and mental health services: Historical obstacles and opportunities. American Journal of Psychiatry 139:616-620.
GOULDNER, A.W. (1979). The future of intellectuals and the rise of the New Class. New York: Continuum.

HARDING, et. al. (1980). Mental disorder in primary health care: a study of their frequency and diagnosis in four developing countries. Psychological Medicine 10:231-241.

KARASEK, R. (1991). The Political Implications of Psychosocial Work Redesign: A Model of the Psychosocial Class Structure. In J.V. Johnson and G. Johansson (eds.) The Psychosocial Work Environment: Work Organization, Democratization and Health. Amityville: Baywood Publishing Company.

KRAMER, M. et al. (in press). The epidemiological basis for primary health care. In B. Cooper (ed) Proceedings of the World Psychiatric Association Section on Epidemiology.

LACHMAN, P.I. \& ZWARENSTEIN, M (199). Child health and health care. South African Medical Journal 77:4676-470.

LOUW, J. (1988). Professionalism as a moral concern. Psychology in Society 9:66-80.

NAVARRO, V. (1974). The underdevelopment of health or the health of underdevelopment. International Journal of Health Services. 4:5-27.

ORMEL, J. et al. (1989). Measuring Change with the General Heealth Questionnaire (GHQ). Social Psychiarry and Psychiatric Epidemiology. 24:227-232.

SALMON, J.W. (1985). Organizing medical care for profit. In J. McKinlay (ed) The Political Economy of Health. London Tavistock.

SARTORIUS, N. (1988). Mental Health in Primary Health Care. International Journal of Menfal Health. 17:5-12.

SCHURMAN, R.A. et al. (1985). When Doctors Listen: Counselling Patterns of Non-Psychiatrist Physicians. American Journal of Psychiarry 142:934-938.

WALT G. AND VAUGHAN, P. (1982). The Primary Health Care Approach: How did it evolve? Tropical Doctor. 12:145-147.

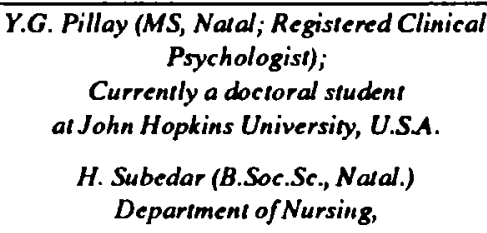

